\title{
Life cycle of Triatoma ryckmani (Hemiptera: Reduviidae) in the laboratory, feeding patterns in nature and experimental infection with Trypanosoma cruzi
}

\author{
Rodrigo Zeledón+, Marlen Cordero', Ricardo Marroquín², Elias Seixas Lorosa ${ }^{3}$ \\ 'Laboratorio de Zoonosis, Escuela de Medicina Veterinaria, Universidad Nacional, Heredia, Costa Rica ${ }^{2}$ Laboratorio de Entomología \\ Aplicada y Parasitología, Escuela de Biología, Facultad de Ciencias Químicas y Farmacia, Universidad de San Carlos de Guatemala \\ Ciudad de Guatemala, Guatemala ${ }^{3}$ Laboratório Nacional e Internacional de Referência em Taxonomia de Triatomíneos, \\ Departamento de Protozoologia, Instituto Oswaldo Cruz-Fiocruz, Rio de Janeiro, RJ, Brasil
}

A cohort initiated with 121 eggs, yielding 105 first instar nymphs (eclosion rate: 86.78\%), allowed us to observe the entire life cycle of Triatoma ryckmani under laboratory conditions $\left(24^{\circ} \mathrm{C}\right.$ and $62 \%$ relative humidity), by feeding them on anesthetized hamsters. It was possible to obtain 62 adults and the cycle from egg to adult took a mean of 359.69 days with a range of 176-529 days (mortality rate of nymphs: 40.95\%). Mean life span of adults was of 81 days for females and 148 days for males. The developmental periods of 4th and 5th nymphs were longer than those of the other instars. This suggests that young siblings have a better chance of taking a hemolymph meal from older ones, in order to survive during fasting periods during prolonged absences of vertebrate hosts from natural ecotopes. The stomach contents of 37 insects showed blood from rodents (15 cases), lizards (7 cases), birds (6 cases) and insect hemolymph (7 cases). Out of 10 insects fed by xenodiagnosis on a Trypanosoma cruzi infected mouse, all but one became infected with the parasite.

Key words: Triatoma ryckmani - life cycle - food preference - T. cruzi

Triatoma ryckmani was first described from a single female specimen found in a military barrack in Valle Department, Honduras, Central America (Zeledón \& Ponce 1972). Later on, three more female specimens were found in airplanes in Miami, United States, one from Honduras and two from Guatemala, the latter together with bromeliad plants in air freight (Lent \& Wygodzynsky 1979). The first male specimen was found near the town of Santa Cruz, Guanacaste Province of Costa Rica (Sherlock \& Morera 1988). Carcavallo et al. (1996) did an external morphological study, with scanning electron microscopy, of another male specimen, collected in Santa Rosa, Guanacaste Province, Costa Rica. More recently, the natural habitats of T. ryckmani were discovered in a semiarid region of El Progreso Department, Guatemala, in cacti (Stenocercus eichlamii) and epiphytic bromeliads (Tillandsia xerographica). In the first instance, all instars of the bug were found in the dry portions of the cactus (Marroquín et al. 2004a, Monroy et al. 2004); in the second situation, colonies of the bugs were also found within the leaves of the bromeliads growing on trees, including the cacti (Marroquín et al. 2004b). The species has also been found in at least four Departments of Nicaragua in small numbers in houses, under intra and peridomiciliary conditions (Marín et al. 2006).

+ Corresponding author: rodrigozeledon@ice.co.cr

Received 28 October 2009

Accepted 26 January 2010
Here we describe, for the first time, the entire life cycle of T. ryckmani under laboratory conditions and the blood patterns of the different instars from specimens collected under natural conditions in Guatemala.

\section{MATERIALS AND METHODS}

A colony was started from specimens captured in June 2005 in bromeliads from a semidesertic area of the Department El Progreso, Guatemala, $89 \mathrm{~km}$ from the capital. The climate is hot and dry with a mean maxima temperature of $34.3^{\circ} \mathrm{C}(2003-2008)$ and a mean annual rain fall of $762.2 \mathrm{~mm}$ for the same period.

A cohort was initiated with 121 eggs laid, during a period of six weeks, by one female captured as a 5th instar nymph. The eggs, obtained during different days, were separated in nine groups of 8-18 eggs, by date of oviposition, in $10 \mathrm{~cm}$ diameter plastic Petri dishes with filter paper on the bottom. They were incubated at a constant temperature with relatively little variation during the experiment (mean \pm SD: $26.0 \pm 0.37$ ) and $62.0 \pm 3.32$ relative humidity.

Each group was fed on anesthetized hamster $(0.25$ $\mathrm{mL}$ of a mixture of Ketamine, 3 parts and xylazine, 1 part) by xenodiagnosis in a small box, during 40-60 minutes, every two weeks and evidence of ecdyses was monitored daily. First instar nymphs were fed at 4-5 days after hatching. Up to the 4 th instar, the nymphs required from 2-4 meals for molting; 4th and 5th instars required 5-7 meals and 9-12, respectively, even though they usually fed readily to repletion.

The sources of blood meals of 37 insects, obtained from $T$. xerographica, were collected individually from the stomach in separate filter papers for each one and 
after eluded they were identified by the capillary tube precipitin test with antisera against 15 different hosts (human, fowl, dog, cat, horse, goat, cow, pig, sheep, rodent, opossum, armadillo, toad, lizard and insect hemolymph), following the procedure of Lorosa et al. (1998).

In addition, 10 individuals ( 2 adult males, 3 4th instar nymphs and 5th instar nymphs) were fed by xenodiagnosis on a mouse infected with a Costa Rican human strain of Trypanosoma cruzi (GA strain) and observed periodically after one week for a period of 30 days.

\section{RESULTS}

Details of the period required for the eggs to hatch and for each nymphal instar to molt until adulthood are presented in Table I. It can be observed that the life cycle of T. ryckmani from 1st up to the 4th instar nymph is rather fast (111.29 as a mean), as compared with the molting periods of the 4th and 5th nymph stages together (226.20 days). The entire life cycle from egg to adult took about a year (359.69 days as a mean of means) with extremes between 176-529 days. The figures for 5 th instar nymphs producing males were $118.29 \pm 28.93$ days as a mean, with extremes between 67-172 days and a total life cycle of 346.96 days as a mean (31 individuals); and the same periods for females were $143.87 \pm 38.96$ days with extremes of 52-236 and a total of 392.54 days, also for 31 specimens. The eclosion rate was high $(86.78 \%)$ and total nymph mortality rate reached $40.95 \%$ during the entire cycle. No mortality was observed in the 5th instar nymphs and the lowest rate was observed in 3rd instar nymphs (3.65\%). The highest mortality occurred at the 4 th stage $(21.51 \%)$. The life span of adults was 81.05 \pm 30.21 days for females with extremes of 78-135 and $148.13 \pm 38.24$ days with extremes of 33-159 for males.

TABLE I

Life cycle of Triatom ryckmani under laboratory conditions

\begin{tabular}{|c|c|c|c|c|}
\hline \multirow[t]{2}{*}{ Stage } & \multirow[t]{2}{*}{$\mathrm{n}$} & \multirow[t]{2}{*}{$\begin{array}{c}\text { Mean } \pm \mathrm{SD} \\
\text { Inter-moulting } \\
\text { periods (range) }\end{array}$} & \multicolumn{2}{|c|}{$\begin{array}{c}\text { Nymph mortality } \\
(\%)\end{array}$} \\
\hline & & & per instar & accumulated \\
\hline Egg & 121 & $\begin{array}{l}22.20 \pm 1.48 \\
(18-26)\end{array}$ & $13.22^{a}$ & $13.22^{a}$ \\
\hline NI & 105 & $\begin{array}{l}25.12 \pm 10.87 \\
(16-62)\end{array}$ & 10.47 & 10.47 \\
\hline NII & 94 & $\begin{array}{c}34.22 \pm 8.49 \\
\quad(16-54)\end{array}$ & 12.76 & 21.9 \\
\hline NIII & 82 & $\begin{array}{l}51.95 \pm 15.61 \\
(24-88)\end{array}$ & 3.65 & 24.76 \\
\hline NIV & 79 & $\begin{array}{l}95.18 \pm 31.60 \\
(50-127)\end{array}$ & 21.51 & 40.95 \\
\hline NV & 62 & $\begin{array}{c}131.02 \pm 36.42 \\
(52-172)\end{array}$ & 0 & 40.95 \\
\hline Total ( & $g$ to & 359.69 & & \\
\hline
\end{tabular}

$a$ : failure to hatch.
The meals found in the stomachs of the insects reacted only against four antisera: fowl, rodent, lizard and insect hemolymph. Out of 37 samples tested, all of different instar nymphs, five did not react against any of the antisera, 29 reacted to at least one of them and three reacted to two hosts at the same time (Table II). The most common host identified was rodent. It is important to notice that seven of the reacting meals revealed that these nymphs had fed on another insect.

Of the 10 insects used in xenodiagnosis on a mouse infected with $T$. cruzi ( 2 adults and 8 nymphs) all but one 4th instar nymph became infected, showing metacyclic trypomastigotes in their dejections.

TABLE II

Meal identification by precipitin test of 37 nymphs of Triatoma ryckmani captured in bromeliad plants

\begin{tabular}{lcccc}
\hline & \multicolumn{4}{c}{ Host $(\mathrm{n} \text { reacted })^{a}$} \\
\cline { 2 - 5 } Instar & Bird & Rodent & Lizard & Insect \\
\hline NII & - & 6 & 1 & 1 \\
NIII & 3 & 8 & 4 & 5 \\
NIV & 2 & 1 & 2 & 1 \\
NV & 1 & - & - & - \\
\hline Total & 6 & 15 & 7 & 7 \\
\hline
\end{tabular}

$a$ : five nymphs (4 III, $1 \mathrm{IV})$ did not react to any antiserum. Three nymphs reacted to two antisera (1 IV to bird and insect, 1 IV to bird and lizard and 1 III to lizard and insect).

\section{DISCUSSION}

The different methodologies used to study the duration of the life cycles of triatomine species under laboratory conditions make it difficult to compare the information gathered. Nevertheless, it is now clear that several intrinsic factors characteristic of a particular species, environmental conditions (mainly temperature and humidity), blood sources, frequency of feeding and other factors can influence the time for the bugs to reach adulthood (Guarnieri et al. 2000, Emmanuelle-Machado et al. 2002, Damborsky et al. 2005).

We also know that, in general, there is an increase in time between molts as the insect grows. Some species have the potential to produce more than one generation a year while others need one or two years or even more to complete the cycle and, in some cases, a full blood meal is generally enough to allow molting (Zeledón et al. 1970, Galvão et al. 1995, Rocha et al. 2004, Luitgards-Moura et al. 2005, Villacis et al. 2008). Some food sources may be insufficient for the completion of the entire cycle of some species, but not necessarily in others (Guarnieri et al. 2000, Rocha et al. 2001, Emmanuelle-Machado et al. 2002).

We have to keep in mind that it is almost impossible to reproduce in the laboratory the conditions under which 
the insects live in nature, especially for those which use particular ecotopes with a suitable microclimate.

The delayed time required for the 4th and 5th nymph instars of T. ryckmani to reach the molting periods deserves special comment. The mean time periods of these instars added and divided by the other three together, yields a rate that is twice that of the first three instars (2.0). If we calculate the same rate in other species of triatomines (sum of developmental periods of 4th and 5 th instar nymphs/sum of developmental periods of 1st, 2nd and 3rd instar nymphs) we find that this is not the case for them. The mean for 15 other species (Triatoma flavida, Triatoma nitida, Triatoma maculata, Triatoma klugi, Triatoma gerstaeckeri, Triatoma lecticularia, Triatoma protracta, Triatoma mexicana, Triatoma dimidiata, Meccus pallidipennis, Meccus longipennis, Rhodnius neglectus, Rhodnius brethesi, Rhodnius ecuadoriencis and Panstrongylus rufotuberculatus) is 1.2 with a range of 0.7-1.8 (Zeledón et al. 1970, Galvão et al. 1995, Martínez-Ibarra et al. 1999, 2003, 2007, 2008, Cabello \& Lizano 2001, Rocha et al. 2001, 2004, Emmanuelle-Machado et al. 2002, Wolf et al. 2004, LuitgardsMoura et al. 2005, Villacis et al. 2008).

This phenomenon in T. ryckmani suggests long periods of fasting by the nymphs, which is probably related to prolonged absences of a vertebrate host from the natural biotopes. One of us (R Marroquín, unpublished observations) has observed a rodent (Reithrodontomys sp.), a bird (Columbina sp.) and a lizard (Ctenosaura palearis), visiting the natural habitats. Under these conditions, larger nymphs, which might endure longer periods of fasting, might serve as a food source for younger nymphs by cannibalism. An evolutionary adaptation process probably allows larger nymphs to prolong their nymphal periods, in order to guarantee the survival of the smaller ones. Cannibalism is a well known phenomenon in triatomines (Zeledón \& Rabinovich 1981) and probably plays an important role in the survival of the nymphs of several species. Hays (1965) observed cannibalism in Triatoma sanguisuga and was able to make a 1 st instar nymph to reach the 4th stage fed only on hemolymph and believes that the process is probably useful in the survival of early-instar nymphs. Cannibalism might occur not only among the nymphs of the same species, but sometime with other types of insects or invertebrates that are readily available (Carvalho-Pinto et al. 2000). The fact that we found insect hemolymph in the stomach contents of seven out of 37 nymphs (1 of 2nd instar, 5 of $3 \mathrm{rd}$ and 1 of 4 th) seems to reinforce this hypothesis. Also, Lorosa et al. (2000) were able to rear Triatoma rubrovaria and Triatoma circunmaculata in the laboratory by feeding them on large roaches of the genus Hormetica. Despite observing high mortality during the life cycle, particularly in the 4th instar, it was possible to obtain some adults of both species by this mechanism.

In spite of the fact that $T$. ryckmani has not been found infected with $T$. cruzi under natural conditions (Marroquín et al. 2004a, Monroy et al. 2004, Marín et al. 2006), the species is able to colonize chicken coops, sometimes in elevated numbers, up to 369 in a single coop (Nakagawa et al. 2005). It also has been found col- onizing houses, in smaller quantities, and adults are also found visiting houses in domestic and peridomestic environments, both in Nicaragua and Guatemala (Monroy et al. 2004, Nakagawa et al. 2005, Marín et al. 2006).

Now that we know that this species becomes easily infected with T. cruzi in the laboratory, its natural infection could be predicted and its epidemiological role in the transmission of Chagas disease in Central American countries needs to be assessed.

\section{ACKNOWLEDGEMENTS}

To Dr. Paul Hanson (School of Biology, University of Costa Rica), for his revision of the manuscript, and to Mr. Heriberto Gutiérrez, for valuable technical help.

\section{REFERENCES}

Cabello DR, Lizano E 2001. Biology of Triatoma flavida Neiva, 1911 (Hemiptera: Reduviidae) under laboratory conditions. Mem Inst Oswaldo Cruz 96: 879-881.

Carcavallo RU, Zeledón R, Jurberg J, Galindez I 1996. Morfologia externa de Triatoma ryckmani Zeledón \& Ponce, 1972 vista através da microscopia eletrônica de varredura. Mem Inst Oswaldo Cruz 91: 727-731.

Carvalho-Pinto CJ, Grisard EC, Loroza ES, Steindel M 2000. Ecological behavioural aspects of Triatoma klugi, a new triatomine species recently described from Rio Grande do Sul State, Brazil. Mem Inst Oswaldo Cruz 95 (Suppl. II): 336-337.

Damborsky MP, Bar ME, Gorla D 2005. Life cycle and reproductive patterns of Triatoma rubrovaria (Blanchard, 1843) (Hemiptera: Reduviidae) under constant and fluctuanting conditions of temperature and humidity. Rev Soc Brasil Med Trop 38: 433-437.

Emmanuelle-Manchado CJ, Koerich LB, Joukoski D de B, Carva1ho-Pinto CJ, Grisard EC, Steindel M 2002. Biology of Triatoma klugi Carcavallo, Jurberg, Lent \& Galvão 2001 (Hemiptera: Reduviidae) under laboratory conditions: effects of distinct blood sources and susceptibility to Trypanosoma cruzi and Trypanosoma rangeli. Mem Inst Oswaldo Cruz 97: 583-587.

Galvão C, Jurberg J, Cunha V, Mello RP de 1995. Biología de Triatoma nitida Usinger 1939 em Laboratório (Hemiptera: Reduviidae). Mem Inst Oswaldo Cruz 90: 657-663.

Guarneri AA, Pereira MH, Diotaitu L 2000. Influence of the blood meal source on the development of Triatoma infestans, Triatoma brasiliensis, Triatoma sordida and Triatoma pseudomaculata (Heteroptera: Reduviidae). J Med Entomol 37: 373-379.

Hays LH 1965. The frequency and magnitude of intraspecific parasitism in Triatoma sanguisuga (Leconte) (Hempitera). Ecology 46: $875-877$.

Lent H, Wigodzinsky P 1979. Revision of the Triatominae (Hemiptera: Reduviidae) and their significance as vectors of Chagas' disease. Bull Am Mus Nat Hist 163: 123-520.

Lorosa ES, Andrade RE de, Santos SM dos, Pereira CA 1998. Estudo da infeção natural e da fonte alimentar do Triatoma sordida (Stal, 1859) (Hempitera: Reduviidae) na região norte de Minas Gerais, Brasil, através da reação de precipitina. Entomol Vect 5: 13-22.

Lorosa ES, Jurberg J, Souza ALA, Vinhães MC, Nunes IM 2000. Hemolinfa de Dictyoptera na manutenção do ciclo biológico silvestre de Triatoma rubrovaria (Blanchard, 1843) e Triatoma circunmaculata (Stal, 1859) (Hempitera: Reudviidae). Entomol Vect 7: 287-296.

Luitgards-Moura JF, Vargas AB, Almeida CE, Magno-Esperança G, Agapito-Souza R, Folly-Ramos E, Costa J, Tsouris P, Rosa- 
Freitas MG 2005. A Triatoma maculata (Hemiptera: Reduviidae, Triatominae) population from Roraima, Amazon Region, Brazil, has some bionomic characteristics of a potential Chagas disease vector. Rev Inst Med Trop Sao Paulo 47: 131-137.

Marín F, Lugo E, Valle S, Zeledón R 2006. Notes on Rhodnius pallescens, Triatoma ryckmani and four other species of triatomines from Nicaragua. Ann Trop Med Parasitol 100: 181-186.

Marroquín R, Bor S, Monroy C 2004a. A mass collection of Triatoma ryckmani (Hemiptera: Reduviidae) from Stenocereus eichlamii (Cactaceae) in the semiarid region of Guatemala. Rev Biol Trop 52: 931-936

Marroquín R, Monroy C, Jaenson TGT 2004b. Triatoma ryckmani (Hemiptera: Reduviidae) in the epiphyte Tillandsia xerographica (Bromeliaceae) in the semiarid region of Guatemala. J Med Entomol 41: 321-323.

Martínez-Ibarra JA, Alejandra-Aguilar R, Paredes-González E, Martínez-Silva MA, Solario-Cibrián M, Nogueda-Torres B, TrujilloContreras F, Novelo-López M 2007. Biology of three species of North American Triatominae (Hemiptera: Reduviidae: Triatominae) fed on rabbits. Mem Inst Oswaldo Cruz 102: 925-930.

Martínez-Ibarra JA, Grant-Guillén Y, Martínez-Grant DM 2003. Feeding, defecation and development times of Meccus longipennis Usinger, 1939 (Hemiptera: Reduviidae: Triatominae) under laboratory conditions. Mem Inst Oswaldo Cruz 98: 899-303.

Martínez-Ibarra JA, Katthain-Duchateau G 1999. Biology of Triatoma pallidipennis Stal 1945 (Hemiptera: Reduviidae: Triatominae) under laboratory conditions. Mem Inst Oswaldo Cruz 94: 837-839.

Martínez-Ibarra JA, Salazar-Schettino PM, Solorio-Cibrián M, Cabrera-Bravo M, Novelo-López M, Vences MO, Montes-Ochoa JY, Nogueda-Torres B 2008. Influence of temperature and humidity on the biology of Triatoma mexicana (Hemiptera: Reduviidae: Triatominae) under laboratory conditions. Mem Inst Oswaldo Cruz 103: 719-723.

Monroy C, Marroquín R, Rodas A, Rosales R, Jaenson TGT 2004. Dis- persion and colonization of Triatoma ryckmani (Hemiptera: Reduviidae) in artificial enviroments in a semiarid region of a Chagas disease endemic area in Guatemala. Acta Trop 91: 145-151.

Nakagawa J, Juárez J, Nakatsuji K, Akiyama T, Hernández G, Macal P, Flores C, Ortiz M, Marroquín R, Bamba T, Wakai S 2005. Geographical characterization of the triatomine infestations in North-central Guatemala. Ann Trop Med Parasitol 99: 307-315.

Rocha D da S, Jurberg J, Carcavallo RV, Cunha V, Galvão C 2001. Influência da temperatura e umidade na biologia de Rhodnius neglectus Lent, 1954 em laboratório (Hemiptera: Reduviidae: Triatominae). Rev Soc Brasil Med Trop 34: 357-363.

Rocha D da S, Santos CM dos, Cunha V, Jurberg J, Galvão C 2004. Ciclo biológico em laboratório de Rhodnius brethesi vector silvestre da doença de Chagas na Amazônia. Mem Inst Oswaldo Cruz 99: 591-595.

Sherlock I, Morera P 1988. Alotipo macho de Triatoma ryckmani Zeledón y Ponce, 1972. Rev Biol Trop 36: 423-428.

Villacís AG, Arcos-Terán L, Grijalva MJ 2008. Life cycle, feeding and defecation petterns of Rhodnius ecuadoriensis (Lent \& León, 1958) (Hemiptera: Reduviidae: Triatominae) under laboratory conditions. Mem Inst Oswaldo Cruz 103: 690-695.

Wolff M, Cuartas E, Velázquez C, Jaramillo N 2004. Development cycle of Panstrongylus rufotuberculatus (Hemiptera: Reduviidae) under laboratory conditions. J Med Entomol 41: 1010-1014.

Zeledón R, Guardia VM, Zúñiga A, Swartzwelder JC 1970. Biology and ethology of Triatoma dimidiata (Latreille, 1811) I Life cycle, amount of blood ingested, resistance to starvation and size of adults. J Med Entomol 7: 313-319.

Zeledón R, Ponce C 1972. Descripción de una nueva especie de Triatoma de Honduras, America Central (Hemiptera: Reduviidae). Rev Biol Trop 20: 275-279.

Zeledón R, Rabinovich JE 1981. Chagas disease: an ecological appraisal with special emphasis on its insect vectors. Ann Rev Entomol 26: 101-103. 